\title{
Cultural Assimilator Technique as a Creative Method for Increasing Intercultural Competence in Multicultural Groups of Students
}

\section{Tangalycheva Rumiya}

St. Petersburg State University, St. Petersburg, Russia rimma98@yahoo.com

Abstract. The purpose of the research is to develop and implement the technique of general cultural assimilators in the process of teaching multicultural groups of students. The work reveals the methodology for constructing cultural assimilators as an addition to language learning in a variety of settings (education, business, public space, family and friendships, everyday life, etc.). It also considers specific cases that help to overcome cultural differences and adapt to the sociocultural context of Russian society.

Keywords: intercultural competence, cultural assimilator, multicultural groups of students

\section{Introduction: Intercultural Competence Concept}

In the course of the internationalization of the Russian higher education system, along with teaching the Russian language, the formation of intercultural competence of students from near, and distant foreign countries acquires particular relevance. Intercultural competence is usually understood as behavior that corresponds to a certain context and is effective in this context [Samovar, Porter, 2004, 302]. A more specific definition of intercultural competence can also be found in the literature. Thus, the American researcher J. Kim defines it as the internal ability of an individual to cope with the challenges of intercultural communication, namely, with cultural difficulties, uncertainty, the position of local residents, as well as the accompanying stress and cultural shock [Kim, 1991, 259].

According to experts, successful (effective) communication can be recognized as such interaction in which sufficiently motivated people with the necessary cultural knowledge and communication skills take part. A sufficient level of motivation means that the communication participants strive to cope with all the goals set for them, that is, they internally form a positive 
image of upcoming events and make maximum efforts to obtain the desired result. Cultural knowledge is associated with the idea of what needs to be done or said at a specific time and in a specific context. Knowledge of this kind is divided into substantive and procedural. Content knowledge includes knowledge of the subject of interest, the right words, their meanings. In other words, knowledge of everything that is necessary in a specific situation of intercultural contact. Procedural knowledge is associated with planning and achieving the desired content. Communication skills are specific patterns of behavior focused on the achievement of specific goals, and vary greatly in different cultures.

The Russian specialist in the field of cultural studies A. P. Sadokhin proposes to consider intercultural competence in broad and narrow senses. In a broad sense, it implies a person's desire to construct a new cultural identity for him/herself, which is achieved through the study of a foreign language and the development of foreign cultural values, attitudes, and patterns of behavior. The main goal of intercultural interaction in this approach becomes the achievement of full or partial acculturation, involving assimilation or integration. In a narrower sense, intercultural competence is aimed at a person's striving for efficiency in communication with carriers of other cultures, even without extensive cultural knowledge. This kind of competence is often necessary for temporary educational, professional or labor migrants. According to the researcher, the second version of understanding intercultural competence requires the creation of special methods for its development [Sadokhin, 2007, 133].

In the scientific literature, there are three main methods for the development of intercultural competence: culture-specific, context-specific and general cultural [Samovar and Porter, 2004, 324-355].

The culture-specific method is focused on preparing people for foreign travel and activities in a specific culture. For example, those who go to work or study in Japan or Korea should be aware that it is customary there to exchange business cards and gifts, use a formal type of communication with business partners, try to avoid harsh, aggressive forms of interactions, and make every effort to maintain harmony and stability in relationship.

A context-specific method for the development of intercultural competence is a detailed preparation of students or professionals for communication in a specific cultural context, for example, for communication in a special business environment, healthcare institution or education organization. 
A general cultural approach to the formation of intercultural competence was first proposed by the American researcher R. Brislin. It is offered to people who "cross cultural boundaries". It is assumed that all people, regardless of their initial characteristics (ethnic, gender, subcultural, age, status, etc.), go through similar stages of adaptation to the host cultural environment. Therefore, there are offered common methods for overcoming culture shock and acculturation, which are effective in any cultural context [Cushner and Brislin, 1996].

All three methods of developing intercultural competence have become quite widespread, primarily in the form of training programs to increase intercultural sensitivity. Intercultural competence building techniques generally serve two purposes:

- to familiarize the audience with cultural differences by staging situations characteristic of certain cultures;

- to familiarize the audience with the typical behavioral manifestations of carriers of other cultures, and on this basis prepare them for the use of new knowledge in a foreign cultural environment. Generally, several types of techniques for increasing intercultural competence can be distinguished: self-analysis, empirical training, field trips and acquaintance with local cultures [Triandis, 2007] as well as a set of cognitive training and cultural assimilator techniques.

In the context of adaptation of foreign students and professionals who come to work in Russia these creative methods have received very limited application. Therefore, the team of St. Petersburg State University prepared a methodology for constructing cultural assimilators for adaptation to life and study in a large Russian city, compiled a training on this technique, and also carried out work to introduce this technique into the educational process [more details can be found: Tangalycheva, 2015, 2014, 2011]. The purpose of this paper is to present this methodology and highlight the work in multicultural groups that is carried out regularly at St. Petersburg State University.

\section{Cultural Assimilator Technique as a Creative Method for Increasing Intercultural Competence}

One of the most effective methods of such training is the cultural assimilation technique. This method allows participants of intercultural contacts to feel themselves in the role of representatives of the host culture (in our case Russian culture). The moderator reveals to newcomers the norms, values and rules of behavior in the receiving society. Thus, it becomes possible to compare and analyze the cultural differences between one's own, native 
and new cultures and to develop the ability to notice these differences, to pay special attention to them. In the course of training, possible conflict situations are considered, as well as guidelines for their effective resolution are given.

A cultural assimilator is a short story based on communication between carriers of two different cultures. In the process of such communication, partners are faced with a problem that complicates the positive course of their interaction. This story offers $4-5$ possible solutions to the problem, of which trainees need to choose only one, the most correct. In addition, an expert interpretation is attached to each possible solution to the problem.

The training program based on the technique of cultural assimilation consists of 100 to 150 stories of interaction between representatives of different cultures. All critical incidents are explained from the point of view of the carriers of Russian culture. Program is recommended for individual work with a computer program or group work in a multicultural group under the guidance of a trainer. After studying this program, students are capable of a better understanding of the subjective culture of Russian culture and, therefore, they are ready for more successful intercultural contacts.

It is worth noting that when constructing assimilators, it is necessary to prepare significantly more stories than will remain in the final version of the training program. Since some will not contain real intercultural differences and will not pass an expert assessment, therefore, they will not be included in the program.

The construction of cultural assimilators is based on interviewing individuals who have extensive experience and knowledge of the two cultures. Any indicator of cultural difference can be included in the training. K. Kushner and R. Brislin in the book "Cultural assimilator. A Practical Guide" proposed 18 topics for the construction of common cultural assimilators: anxiety; unconfirmed expectations; affiliation; uncertainty; opposition to prejudice; communicative and linguistic knowledge; roles; individualism / collectivism; rituals / superstitions; social hierarchy / class and status; values; work indicators (problem solving; focus on completing tasks or on interpersonal relationships; decision making practices); orientation in time and space; categorization; differentiation; distinction between "insiders" and "outsiders" of the group; styles of assimilation of cultural knowledge; attribution [Cushner and Brislin, 1996].

This form of training develops participants' cognitive breadth of thinking. Cognitive complexity, in turn, helps to view the subjective culture of another 
group as "suitable", therefore, in relation to it, the level of prejudice and stereotypical judgments decreases. At the same time, training based on cultural assimilators does not always stimulate sympathy for another cultural group or reduce social distance towards it. The development of sympathy depends on the positive experience of interaction with another group. Knowing how another group thinks and perceives the world around them does not change the emotional attitude towards it. Social distance often depends on the norms of our own home group and if our group norms encourage the formation of friendships with another group, we will be more inclined to establish them than when they hinder us.

Another limitation of the cultural assimilation technique is that it does not change behavior itself. It is one thing to know how to behave, and quite another to really behave correctly. To achieve this, it is necessary to undergo training in behavior modification and acquire the skills of "new" behavior.

\section{Methodology of Applied Research}

The object of this applied research was foreign citizens living in St. Petersburg for at least three months. The following target groups of foreign citizens were distinguished:

- personnel of foreign, joint and Russian companies and institutions;

- undergraduate and graduate students;

- foreign citizens married to residents of Russian cities;

- labor migrants.

The study participants were also divided into several groups by region:

- representatives of Western cultures (USA, Western Europe, including Latvia, Lithuania and Estonia);

- representatives of the Far Eastern countries;

- representatives of the CIS countries;

- people from African countries.

The subject of the research is the intercultural communication of foreign citizens from various countries with the residents of St. Petersburg, as well as the problems and difficulties faced by participants in the course of international cooperation.

Two qualitative methods of collecting and processing empirical data were used:

1) semi-structured interviews of experts with communication experience and knowledge of the specifics of two different cultures; 
2) series of focus groups combined with interactive video filming.

The study involved 70 people representing five regions and cultures (East, West, Africa, CIS), or 32 countries. The largest number of participants was represented by foreigners from Western countries (27 people). Foreign participants were represented by 44 men and 26 women. The age of the participants is from 17 to 59 years old. The study involved employees of foreign, joint and Russian companies and diplomatic services, teachers of foreign languages, students, graduate students, persons married to foreign citizens, as well as forced migrants who came to St. Petersburg in order to find better living conditions and earnings.

Almost all of them spoke Russian more or less well. The only exceptions were a few high-status employees of foreign companies (they were interviewed in English) and a few young labor migrants from Central Asia who graduated from school after the collapse of the Soviet Union and therefore speak Russian poorly.

Highly qualified employees of foreign companies and diplomatic services, as well as some graduate students, were invited as experts with extensive experience in communication in different cultures. There were interviewed 10 foreign teachers working in various educational institutions of St. Petersburg and teaching their national languages. The method of individual interviews has certain advantages over the group method as the organizers of the study themselves came to the informants at a convenient time and place. In addition, some of the informants, despite the fact that they had lived in Russia for several years, did not speak Russian, so English could be used during the individual conversation. A total of 25 expert interviews were received.

Four focus groups were conducted with the rest of the study participants. The objective of this part of the study was to identify free associations and stories connected with living and studying (working) in St. Petersburg for the further construction of cultural assimilators.

The most contrasting patterns of interactions were recorded in contacts with representatives of Western and Eastern cultures. It should be noted that the strategies of acculturation of representatives of these cultures differ greatly. Foreigners from Western Europe and the United States tend to associate the difficulties of their adaptation with the lack of culture of local residents, while foreigners from Eastern countries make every effort to understand the motives of behavior of Petersburgers and adapt to them. 


\section{Results: Construction of Cultural Assimilator and Elaboration of Training Program}

As a result of the applied research a large number of cases, stories and plots of intercultural interactions between foreign citizens and residents of St. Petersburg were collected. The tasks of the authors of general cultural assimilators were as follows.

1. Use interview materials and select specific situations for constructing assimilators.

2. State each specific situation in literary Russian, without stylistic and grammatical errors.

3. Identify the main communication problem in each specific situation.

4. Think over and write four possible solutions to the identified problem, only one of which is correct from the point of view of representatives of the Russian culture.

5. Prepare an expert interpretation of each of the four answer options; each of these interpretations should immerse foreigners in the context of local culture.

Let's consider the process of constructing a general cultural assimilator using a specific example.

At the first stage, we select the situation told by the informant. In our example, this is a young Korean woman studying at one of the St. Petersburg universities.

"You know in Korea, foreigners and Koreans are very different. Nobody asks a foreigner for directions or the bus number. When I was standing at a bus stop in St. Petersburg, Russian "babushka" asked me: "Tell me, please, which trolleybus will get me to the Vasileostrovskaya metro station? at that time I had just arrived in Russia and did not know... I was so amazed: how could she approach me, a foreigner, and ask for directions? I was so amazed... And she asks for directions... in Russian, speaks Russian... it was so strange... Now I am already adapted and if they don't even ask me... I myself tell everyone what, how much, which minibus goes where; I tell it by myself."

Then, with the help of leading questions, it was found out how the situation was resolved. It turned out that, seeing the confusion of a young Korean woman, the elderly Russian woman waved her hand and ran on. As you can see, the situation is stated quite clearly, but in not the best Russian language. Also, without further questioning, this story was not complete. 
At the second stage, we present the same situation in the normative Russian language without stylistic and grammatical errors and give it the form of a small story. It turns out the following version.

A young Korean woman came to St. Petersburg a few days ago to study at one of the universities. Now she was walking to the apartment she had rented the day before. The girl felt extremely insecure: she could hardly speak Russian and was very careful on the street, since she did not yet know either the city or its inhabitants at all. She also tried to remember the way to her place. She felt like a stranger in this unfamiliar district.

Suddenly, an elderly Russian woman who in Russia is often called "babushka" approached her and asked: "Could you tell me how to get to the Vasileostrovskaya subway station?". The Korean woman was confused because she did not quite understand what the passerby wanted from her. She smiled politely, trying with all her appearance to show that she did not understand her question. The elderly woman only looked at the girl with condemnation, waved her hand and hurried on. When, finally, the Korean woman realized what the elderly woman wanted, she was deeply amazed that the local resident had not noticed that she was a foreigner. In her own country, she is used to unmistakably distinguishing foreigners within a crowd.

At the third stage, we identify the problematic situation in this story and formulate a question related to the behavior of a local resident: Why did an elderly Russian woman turn to a Korean lady with a question about how to get to the subway station?

An important issue in our research is that the question should be formulated in such a way as to explain to foreign citizens the motives for the behavior of residents of Russian society, in our case citizens of St. Petersburg.

At the fourth stage, we construct four possible answers to the question posed, only one of which is correct.

1. Due to her elderly age, a local resident could not see well.

2. An elderly woman had no idea that foreigners, who did not speak Russian and did not know the city well, could walk unaccompanied.

3. According to the elderly woman, the young Korean woman was no different from other passers-by. (CORRECT ANSWER)

4. The elderly woman did not think that the foreigner did not speak Russian.

At the fifth stage, expert interpretations are constructed for each answer. These interpretations are intended to immerse foreign citizens in the context of local culture. In the process of preparing interpretations, the method- 
ological approaches to the study of intercultural communication by E. Hall, G. Hofstede and other researchers were taken into account [Kluckhohn, Strodtbeck, 1960; Inglhart, Vel'tsel', 2011; Hall, 1959; Hofstede, 1991, 2001; L'uis, 2001]. At the same time, the authors of cultural assimilators relied on their cultural and everyday experience of life in Russia, as well as their professional knowledge in the field of intercultural communication.

1. We cannot rule out this possibility. However, in the description of the situation there is no indication that the elderly local woman had vision problems. On the contrary, we know that the woman was very mobile, quick and well oriented in the situation. After all, she did not wait for the young Korean woman to understand what she had wanted from her, but, waving her hand, hurried on. We have no reason to believe that she saw poorly. Try another answer.

2. It is quite understandable that people who first come to a new country can usually count on support from local residents. At the same time, many tourists and migrants explore the new space on their own from the first days. A foreigner walking along the city streets unaccompanied by friends or acquaintances is not unusual in St. Petersburg. However, the elderly local resident hardly ever thought about who to ask for directions. She just needed to get to the metro station faster. Try another answer.

3. This is the correct answer. Representatives of more than 120 ethnic groups and nationalities live in St. Petersburg. On the streets of the city you can meet people with eastern and western roots, visitors from northern and southern regions. All these people have the most varied appearance: hair color, eyes, height, facial features, etc. Often on the streets of Russian cities you can see people from Korea who have lived in St. Petersburg for several generations. They, as a rule, speak Russian fluently, without an accent, know the city space very well and can help a passer-by by pointing the right direction. Therefore, the old Russian woman, who asked the young Korean lady how to get to the metro station, simply had no idea that she was a foreigner.

4. This is partly the correct answer. Many guests of St. Petersburg speak Russian quite well, and, of course, an elderly woman could not assume in advance that a young Korean woman does not speak Russian. However, this explanation does not fully disclose the situation. Please refer to another answer.

To create a training program on the technique of cultural assimilator, we collected 130 cultural assimilators, united in several headings. The section "Business" contains situations related to the specifics of doing business in Rus- 
sia: distribution of profits, hiring employees, negotiating, the role of informal relationships, attitude to work, communication errors, etc.

The "Education" section reflects the relationship between teachers and students, the organization of the educational process in Russian universities, communicative failures associated with misunderstanding the meaning of words and grammatical structures, ignorance of the rules, norms and expectations of representatives of different cultures in the field of education, etc.

The topic "Space of the city" includes stories dedicated to the peculiarities of the functioning of urban space: problems of politeness of citizens, the relationship "between fathers and children"; transport, road conditions; smoking, drinking alcoholic beverages; variety of styles of behavior of Petersburgers, etc.

The topic "Home and Family" covers situations such as the culture of feasts, food culture, home improvement, relationships with neighbors and family members, omens, superstitions that guide local residents at home, etc.

The section "Leisure and Entertainment" contains a description of episodes from intercultural interactions in the free time: while shopping, visiting museums, restaurants, cinemas, celebrating birthdays, etc.

The last section "Services and Services" addresses situations related to medical and educational services, as well as serving people in shops, banks, post offices, repair shops, restaurants and cafes.

All these headings include differences in verbal and non-verbal communication, in roles (gender, age, status), differences in rituals, holidays, superstitions, values and expectations. In addition, great attention is paid to differences in the perception of space and time, in relation to collectivism / individualism.

\section{Conclusions: Prospects for the Use of Training Program on the Technique of Cultural Assimilator}

The results of our study and the developed cultural assimilators were shared with all study participants. According to employees of foreign companies, diplomatic services, teachers of their national languages working in St. Petersburg, as well as students and postgraduates, the cultural assimilators turned out to be useful for them. They independently worked on situations of intercultural interactions and expert explanations of them, and, as a result of which, they discovered many previously unknown nuances of intercultural communication. 
Currently, the training materials are used primarily to work with students in multicultural classrooms in the process of teaching a number of courses at St. Petersburg State University on intercultural communication, sociology of culture, social communications, social work, etc. After getting acquainted with the situations from the training program, students are invited to independently collect material and develop similar episodes with original stories. It is worth noting that the greatest difficulties in the work of students are caused by the requirement to formulate the main problem of the selected situation, as well as the requirement to identify 4-5 relevant options for resolving a difficult situation. To do this, students should have a sufficiently rich imagination and some personal experience of intercultural communication. Often, students do not have sufficient knowledge about the culturally specific context of representatives of other cultures who are involved in the assimilator story.

At the same time, conducting classes on the technique of cultural assimilation allows students to significantly expand their cultural outlook, gives them the idea that the culture of the host country should be perceived based on its own assessment criteria, and relieves students of excessive ethnocentrism. They begin to understand that intercultural contacts can bring satisfaction and pleasure, that these contacts can be effective and lead to the successful fulfillment of educational and professional tasks.

As the experience of several years of popularizing the developed training on the technique of cultural assimilation has shown, the important target groups of such work, in addition to students and university teachers, could be:

- journalists who cover interethnic, intercultural relations in the Russian sociocultural environment;

- leaders of diasporas of various national and ethnic groups in Russian cities;

- religious leaders in large cities;

- workers of social services, local self-government bodies and workers of non-profit organizations involved in the harmonization of interethnic and intercultural relations.

Further methodological and practical work on the technique of cultural assimilation should be associated with the development of culturally-specific situations of interaction in different settings and cultural groups. Since the problem of labor migration from Central Asia is the most urgent in recent years for many large cities of Russia and for the country as a whole, it is prob- 
ably necessary to concentrate on solving this problem. At the same time, this kind of work should not be carried out with the labor migrants themselves, but with representatives of those administrative bodies that will be responsible for the adaptation of migrants. Nowadays labor migrants in Russia are mainly concerned with survival and earning a livelihood. In addition, the level of Russian language proficiency among the representatives of the young generation of migrants who graduated from school after the collapse of the USSR does not allow them not only to receive specific intercultural knowledge and skills, but also to adapt to the most elementary requirements of the host society. To help them fully master the new socio-cultural environment, it would be better at first to train moderators and social workers who can carry out activities on the adaptation of labor migrants and their children.

\section{Acknowledgment}

This work was supported by the Core University Program for Korean Studies through the Ministry of Education of the Republic of Korea and the Korean Studies Promotion Service of the Academy of Korean Studies (AKS-2016-OLU-2250002)

\section{References:}

1. L. A. Samovar, R. E. Porter. Communication Between Cultures. Thomson Wadsworth, UK (2004).

2. Y.Y. Kim. Intercultural Communication Competence: A Systems-Theoretic View. Cross- Cultural Interpersonal Communication, Newbury Park, CA: Sage (1991), pp. 259-275.

3. A. P. Sadokhin. Meshkul'turnaya kompetentnost' [Intercultural competence]. Zhurnal sotsiologii i sotcial'noi antropologii [Journal of Sociology and Social Anthropology], Vol. X, № 1 (2007), pp. 125-139.

4. K. Cushner, R. W. Brislin. Intercultural Interactions: A Practical Guide (Second ed.) Sage Publications, Beverly Hills, CA (1996).

5. G. Triandis. Kul'tura i sotcial'noe povedenie [Culture and social behavior]. Forum, Moscow (2007).

6. R.K. Tangalycheva. Mezhkul'turnaya kommunikatsiya i akkul'turatsiya (opyt zarubezhnyh issledovaniy [Intercultural communication and acculturation (experience of foreign research)]. Sotsiologiycheskie issledovaniya [Sociological research], № 7 (2015), pp. 89-98.

7. R.K. Tangalycheva. Akkul'turatsiya vremennyh migrantov iz zarubezhnyh stran $\mathrm{v}$ krupnom rossiyskom goroge [Acculturation of temporary migrants from 
foreign countries in a large Russian city]. Observatoriya kul'tury [Observatory of Culture], № 1 (2014), pp. 43-47.

8. R. K. Tangalycheva. Problemy akkul'turatsii vremennyh migrantov v krupnom possiiskom gorode: kul'turnye razlichiya $\mathrm{v}$ neverbal'noy kommunicatcii [Problems of acculturation of temporary migrants in a large Russian city: cultural differences in non-verbal communication]. Sotsiologitcheskiy zhurnal [Sociological journal], № 3 (2011), pp. 24-39.

9. F. R. Kluckhohn, F. L. Strodtbeck. Variations in Value Orientations.: Row and Peterson, New York (1960).

10. R. Inglhart, K. Vel'tsel'. Modernizatsiya, kul'turnye izmereniya i democratiya: Posledovatel'nost' chelovecheskogo razvitiya [Modernization, Cultural Change and Democracy: Sequencing Human Development]. Novie izdatel'stvo, Moscow (2011).

11. E. T. Hall. The Silent Language. Doubleday, Garden City, N. Y. (1959).

12. G. Hofstede. Culture and Organization: Software of the Mind. McGrow-Hill, London (1991).

13. G. Hofstede. Culture's Consequences: Comparing Values, Behaviors, Institutions, and Organizations Across Nations, 2nd ed. Sage Publications, CA (2001).

14. R. D. Luis. Delovye kul'tury v mezhdunarodnom biznese. Ot stolknoveniya $\mathrm{k}$ vzaimoponimaniyu [Business cultures in international business. From collision to mutual understanding]. Delo, Moscow (2001).

DOI 10.15826/B978-5-7996-3081-2.17

\title{
Laboratory of Linguistic Meanings Within Communication Trends of the Post-Literacy Era
}

\author{
Ivanyan Elena', Gurova Irina² \\ 1 Samara State University of Social Sciences and Education, Samara, Russia \\ ${ }^{2}$ Samara State University of Social Sciences and Education, Samara, Russia \\ Corresponding author: Ivanyan Elena, ivanyan@pgsga.ru
}

Abstract. The article investigates the problem of forming polyliteracy within the framework of the University Laboratory of Linguistic Meanings. The choice of activities is justified: ontolinguistics; Russian as a foreign language; linguoecol- 